\title{
Does State-Owned Capital Manipulate Earnings Responses in China?
}

\author{
Dehong Wang*, Yue Wu \\ International Business School, Beijing Foreign Studies University, Beijing, China \\ Email: *wangdehong@bfsu.edu.cn
}

How to cite this paper: Wang, D.H. and Wu, Y. (2016) Does State-Owned Capital Manipulate Earnings Responses in China? Journal of Mathematical Finance, 6, 685698.

http://dx.doi.org/10.4236/jmf.2016.65048

Received: June 23, 2016

Accepted: November 7, 2016

Published: November 10, 2016

Copyright $\odot 2016$ by authors and Scientific Research Publishing Inc. This work is licensed under the Creative Commons Attribution International License (CC BY 4.0).

http://creativecommons.org/licenses/by/4.0/

\begin{abstract}
This paper analyzes the relation between state-owned capital factor and earnings quality through Earnings Response Coefficient (ERC) in Chinese stock markets. Our research finds that the ERC is significantly associated with the role state-owned capital plays in the equity structure of the companies in Chinese stock markets. Further analysis indicates that companies controlled by state-owned capital tend to have a better earnings quality.
\end{abstract}

\section{Keywords}

State-Owned Capital, ERC, Equity Structure, Earnings Quality

\section{Introduction}

Earnings quality has always been an important factor in evaluating the profitability of a company, and it is also frequently related with its accounting frauds. These accounting frauds, however, usually reflect problems in corporate governance, which are closely associated with corporate equity structure. Some Chinese companies are very different compared to their western counterparts in terms of corporate equity structure. These companies are either controlled by state-owned capital or influenced by state-owned capital. In other words, the role of state-owned capital should not be neglected in a company's equity structure as well as corporate governance in the companies in Chinese stock markets. Furthermore, these companies are usually big in terms of assets and have stronger implications in stock markets. Both investors and analysts have to pay great attention to these companies.

Before 2007, most equity of state-owned capital had great restrictions or was nontradable in Chinese stock markets. After 2007, with the completion of the equity reform in Chinese companies, state-owned capital in Chinese companies was released to enter 
stock market. The role state-owned capital plays in Chinese companies has big changes after 2007. What are the influences of state-owned capital to the earnings quality of Chinese companies? Existing studies mostly concentrate on the situations before 2007 when the reform of non-tradable shares was not completed. What are the situations after 2007 ?

In 2007, the reform of non-tradable shares (mostly were state-owned capital) was completed for most of listed companies, and a more market-oriented trading system was established. Under such trading system, state-owned capital could be more flexible in manipulating corporate performance and earnings quality in Chinese companies. Leveraged by Earnings Response Coefficient (ERC), this study compares the earnings quality of Chinese companies with different proportions of state-owned capital in their equity structures. Research reveals that the earnings quality of Chinese companies has close relation with state-owned capital in corporate equity structure. The higher the proportion of state-owned capital in a company's equity structure is, the stronger market reactions to its earnings announcements are. This shows an interesting phenomenon in China stock market, the more state-owned capital holds in a company, the better its earnings quality is. State-owned capital, at least in earnings quality, plays a positive role in Chinese stock markets despite of the other effects it brings to Chinese companies.

There are five sections in this paper. Section 2 is a brief review about existing literatures on the relationship between state-owned capital and earnings situation of a company; Section 3 is research design, including hypothesis development, sample data description and correlation analysis; Section 4 is research analysis, including empirical and robust tests; Section 5 concludes this paper; where we also discuss some of the limitations of this study.

\section{Literature Review}

Generally speaking, there are three types of ideas in current literature on the influences of state-owned capital to the earnings of a company. These ideas are either no influences, positive influences or negative influences.

The first type of idea says that there are no significant evidence to prove the close tie between earnings performance, earnings management, earnings persistence, corporate governance and the state-owned capital in a company [1] [2].

The second type of idea regards that state-owned capital has positive impact on the earnings behaviors of companies compared to those without state-owned companies. For examples, there are more earnings management in the companies without stateowned capital than those with state-owned capital [3]; when controlling shareholders are state-owned capital, the earnings qualities of companies are higher [4] [5]; and when major shareholders are not state-owned capital, the earnings qualities are lower [6]. In addition, companies with state-owned capital controlling in board of directors have significantly lower earnings management [7].

However, the third type of idea is more popular in scholars. They emphasize that state-owned capital in companies may have negative implications on corporate gover- 
nance [8], earnings performance [9], earnings capability [10], accounting fraud [11], earnings quality [12] [13], financial report restatement [14], and accounting conservatism [13]. Their think that the management of the companies with state-owned capital is more short-term on corporate earnings quality and earnings performance because they need to have a better performance within a time period as short as possible so that they can have more opportunities to be promoted to higher positions by SASAC (Stateowned Assets Supervision and Administration Commission, a Chinese governmental authority responsible to supervise state-owned capital invested in companies). In other words, the management of companies with state-owned capital may not have long-term career objectives in the companies, and therefore they are likely to pursue short-term earnings performance and may sacrifice the earnings quality if conflicting with shortterm earnings performance.

The above explanation is just one side of a coin since we can also explain from another side the same coin. We think that the management of companies with stateowned capital, especially for those that state-owned capital has controlling power in boards of directors, has less financial relationship with corporate earnings performance. In other words, the management of companies with controlling state-owned capital has less pressures on earnings performance from corporate owners compared to those with private investors as major shareholders. The reason is that there are no real bosses in state-owned capital controlled companies to personally supervise them and to exert private pressures on earnings performance like the situation in those companies without state-owned capital. Therefore, when there are great conflicts between corporate earnings performance and management's personal career and reputational risks, the management may not feel necessary to sacrifice their reputations to make accounting frauds on earnings quality or manipulate corporate earnings performance. In this way, we think that the earnings quality of state-owned capital controlled companies may be closer to the real situations when facing pressures of corporate earnings performance. Market investors may also think that such company's earnings announcement may be more reliable, and market responses to these earnings discloses may be more proactive. In summary, we think that state-owned capital controlled companies may have better or stronger earnings responses in market.

\section{Research Design}

In this section, we firstly make research hypotheses on the relationships between state-owned capital and corporate earnings quality. Then, we collect data sample from Shanghai Stock Exchange, the biggest stock exchange in China. The descriptive statistics and correlation analysis on these data sample are also stated in this section.

\subsection{Research Hypotheses}

We suppose that state-owned capital has a more flexible way to be manipulated after the complete of non-tradable shares reform. Therefore, state-owned capital would behave just like private capital, and tend to flow into enterprises of high quality and to 
flow out of those which are not. The most obvious indicator to measure the inflow and outflow is the change of holding ratio of state-owned shares. Thus, we develop the first hypothesis:

Hypothesis A: Earnings quality of those companies of which the holding ratio of state-owned shares decreases is lower than those whose holding ratio of state-owned shares does not decrease.

Another important standard to measure the inflow and outflow of state-owned capital is the convert of identity of the largest shareholder. Thus, we develop the second hypothesis:

Hypothesis B: Earnings quality of those companies whose largest shareholder is converted from private to state-owned is higher than those whose largest shareholder converts in the opposite way.

We also suppose that since the conflicts might occur between private capital and state-owned capital at the same company, the capacity of controlling the company is of great significance in decision-making, the performance of the enterprise and corporate governance. As previously mentioned, to some degree, whether the structure of governance is distorted could be reflected by earnings quality. We believe that those companies controlled by state-owned capital tend to have a better performance, especially those heavily controlled due to the lack of resistance of implementing policies. Thus, we develop the third hypothesis:

Hypothesis C: The earning quality is higher if the holding ratio of state-owned shares is higher than those whose holding ratio of state-owned share is lower provided the enterprise is not totally private-owned.

\subsection{Empirical Model}

According to the studies in existing literature [4] [12], we set up the following model for the empirical tests afterwards, named as the general model in this study. This model is the general model that is used as the fundamental model in this paper. Different hypothesis is tested by the same model, but data are grouped by different indicators under different standards.

$$
\begin{aligned}
\text { MODY }= & \alpha 1+\alpha 2 * \text { MODX }+\alpha 3 * \text { SIZE }+\alpha 4 * \text { LEVRATIO } \\
& +\alpha 5 * \text { IDXYRRET }+\alpha 6 * \text { INDUSTRY }
\end{aligned}
$$

The variables in the general model are defined in the following Table 1. MODY is the dependent variable, and MODX is the independent variable. SIZE, LEVRATIO and IDXYRRET are controlling variables. INDUSTRY is a dummy variable.

In order to test Hypothesis A, B and C, we define the three dummy indicators for grouping sample data, DELSTATEPCT, LGSTCHGIDX and CTRLPCTSTATE respectively. There definitions are as below in Tables 2-4.

\subsection{Sample Data and Descriptive Statistics}

The source of sample data used in this paper is RESSET Database. Since the subject we study is the ERC after the complete of non-tradable shares reform, data of Shanghai main board market from 2007 to 2014 are selected. To make the results of empirical 
Table 1. Variable definitions in the general model.

\begin{tabular}{|c|c|c|}
\hline Name & Definition & Implication \\
\hline MODY & $\begin{array}{l}\text { The difference between the natural logarithm of } \\
\text { this year's closing price and the natural logarithm } \\
\text { of last year's closing price. }\end{array}$ & $\begin{array}{l}\text { The variable to measure the annual } \\
\text { return of per stock in the market. }\end{array}$ \\
\hline MODX & $\begin{array}{l}\text { The difference between this year earnings per } \\
\text { share (EPS) and last year's earnings per } \\
\text { share (EPS). }\end{array}$ & $\begin{array}{l}\text { The variable to measure the annual } \\
\text { return of per stock in book value. }\end{array}$ \\
\hline SIZE & Natural logarithm of total assets. & $\begin{array}{l}\text { To control the influence brought by } \\
\text { the size of the company. }\end{array}$ \\
\hline LEVRATIO & The asset-liability ratio. & $\begin{array}{l}\text { To control the debt/asset structure } \\
\text { of a company. }\end{array}$ \\
\hline IDXYRRET & The return of Shanghai A Share Index of that year. & $\begin{array}{l}\text { To control the influence by the } \\
\text { whole market. }\end{array}$ \\
\hline INDUSTRY & $\begin{array}{l}\text { Types of industries sorted by CSRC of } 2012 \text {, } \\
\text { financial industry is excluded due to the capital } \\
\text { structural difference. }\end{array}$ & $\begin{array}{l}\text { To control the influence generated } \\
\text { by the differences between different } \\
\text { industries. }\end{array}$ \\
\hline
\end{tabular}

Table 2. Definition of DELSTATEPCT for Hypothesis A.

\begin{tabular}{cl}
\hline Name & Definition \\
\hline DELSTATEPCT & $=1$ if the holding ratio of state-owned shares of this year is higher than last year. \\
& $=0$ if the holding ratio of state-owned shares of this year is higher than last year.
\end{tabular}

Table 3. Definition of LGSTCHGIDX for Hypothesis B.

\begin{tabular}{cl}
\hline Name & Definition \\
\hline LGSTCHGIDX & $=1$ if the largest shareholder is converted from the private to the state, \\
& 0 if the largest shareholder is converted from the state to the private.
\end{tabular}

Table 4. Definition of CTRLPCTSTATE for Hypothesis C.

\begin{tabular}{ll}
\hline NAME & \multicolumn{1}{c}{ DEFINITION } \\
\hline CTRLPCTSTATE & $\begin{array}{l}\text { market provided the company is not totally private. } \\
=0 \text { if the holding ratio of state-owned shares is lower than the median of the whole } \\
\text { market provided the company is not totally private. }\end{array}$ \\
\hline
\end{tabular}

research more convincing, several measures are taken including:

All the data of companies in financial industry are excluded due to particularity of financial structure in this industry; All the companies whose listed status is not norm, such as Special Treatment (ST), Particular Treatment (PT) et al, are excluded; Sample with missing values or outliers in variables we study are excluded, such as closing price is negative, total asset is negative, and so on; To avoid extreme values, records of total asset are winsorized at the level of 0.01 . Here is the descriptive statistics of variables we use (Table 5). 
Here is the descriptive statistics of variables we use after grouping with the first indicator, DELSTATEPCT (Table 6 and Table 7).

From the figures above, the phenomena of state-owned capital reduction is observed clearly. The amount of observations for DELSTATEPCT $=1$ is much fewer than DELSTATEPCT $=0$. We find that the reform of non-tradable shares is one of the significant factor, and other factors, such as the dilution of state-owned capital due to additional shares offerings, especially private additional shares offerings.

Another fact is that performances of samples whose DELSTATEPCT is 1 are better than those whose DELSTATEPCT is 0 , which could be inducted from MODY, which is the first order difference of natural logarithm of the yearly closing price.

Here is the descriptive statistics of variables we use after grouping with the second indicator, LGSTCHGIDX (Table 8 and Table 9).

Table 5. Descriptive statistics of variables.

\begin{tabular}{cccccc}
\hline Variable & Obs. & Mean & Std. Dev. & Min & Max \\
\hline MODY & 4897 & -0.0573 & 0.6197 & -2.7553 & 2.0321 \\
MODX & 4897 & -0.0037 & 0.2860 & -4.4200 & 4.1500 \\
IDXYRRET & 5676 & 0.1561 & 0.5163 & -0.6538 & 0.9614 \\
LEVRATIO & 5676 & 0.4856 & 0.2155 & 0.0004 & 3.1462 \\
SIZE & 5676 & 21.9686 & 1.2296 & 19.2886 & 25.4349 \\
INDUSTRY & 5676 & 5.0844 & 3.7068 & 1.0000 & 17.0000 \\
\hline
\end{tabular}

Table 6. Descriptive statistics when DELSTATEPCT $=1$.

\begin{tabular}{cccccc}
\hline Variable & Obs. & Mean & Std. Dev. & Min & Max \\
\hline MODY & 1059 & -0.0878 & 0.8014 & -2.3324 & 1.7565 \\
MODX & 1059 & -0.0259 & 0.3165 & -4.4200 & 1.6400 \\
IDXYRRET & 1059 & 0.0623 & 0.5867 & -0.6538 & 0.7980 \\
LEVRATIO & 1059 & 0.4976 & 0.2042 & 0.0004 & 1.8931 \\
SIZE & 1059 & 22.0213 & 1.2184 & 19.2886 & 25.4349 \\
INDUSTRY & 1059 & 4.9377 & 3.5241 & 1.0000 & 17.0000 \\
\hline
\end{tabular}

Table 7. Descriptive statistics when DELSTATEPCT $=0$.

\begin{tabular}{cccccc}
\hline Variable & Obs. & Mean & Std. Dev. & Min & Max \\
\hline MODY & 262 & -0.0637 & 0.6723 & -1.9950 & 1.7938 \\
MODX & 262 & 0.0296 & 0.3083 & -1.3200 & 1.3900 \\
IDXYRRET & 262 & 0.0269 & 0.4673 & -0.6538 & 0.7980 \\
LEVRATIO & 262 & 0.4731 & 0.2055 & 0.0069 & 0.8731 \\
SIZE & 262 & 22.4152 & 1.0968 & 19.2886 & 25.4349 \\
INDUSTRY & 262 & 5.0305 & 3.5254 & 1.0000 & 17.0000 \\
\hline
\end{tabular}


Table 8. Descriptive statistics when LGSTCHGIDX $=1$.

\begin{tabular}{cccccc}
\hline Variable & Obs. & Mean & Std. Dev. & Min & Max \\
\hline MODY & 54 & 0.0089 & 0.7381 & -1.3900 & 1.2358 \\
MODX & 54 & 0.0702 & 0.3287 & -1.0500 & 1.1000 \\
IDXYRRET & 54 & 0.0630 & 0.5389 & -0.6538 & 0.7980 \\
LEVRATIO & 54 & 0.4578 & 0.2165 & 0.0149 & 0.8525 \\
SIZE & 54 & 22.1319 & 1.1271 & 19.2886 & 25.1615 \\
INDUSTRY & 54 & 4.9815 & 3.2707 & 1.0000 & 16.0000 \\
\hline
\end{tabular}

Table 9. Descriptive statistics when LGSTCHGIDX $=0$.

\begin{tabular}{cccccc}
\hline Variable & Obs. & Mean & Std. Dev. & Min & Max \\
\hline MODY & 261 & -0.1508 & 0.7959 & -2.0850 & 1.6386 \\
MODX & 261 & -0.0245 & 0.3238 & -2.2300 & 1.2300 \\
IDXYRRET & 261 & 0.0334 & 0.5914 & -0.6538 & 0.7980 \\
LEVRATIO & 261 & 0.5002 & 0.1965 & 0.0019 & 0.9601 \\
SIZE & 261 & 21.9270 & 1.1329 & 19.2886 & 25.4349 \\
INDUSTRY & 261 & 5.0038 & 3.5372 & 1.0000 & 17.0000 \\
\hline
\end{tabular}

Figures above illustrate the similar phenomenon previously discussed, including the reduction of state-owned capital and better performance for enterprises which are preferred by state-owned capital.

Here is the descriptive statistics of variables we use after grouping with the third indicator, CTRLPCTSTATE (Table 10 and Table 11).

However, the variable MODY performs differently comparing with previous two sets of data. Those whose state-owned share ratio is above median have a lower MODY than those below the median. Another fact we notice is that the difference between the amounts of observations is not as obvious as previous tables, both from the perspective of absolute numbers and the ratio.

\subsection{Correlation Analysis on Model Variables}

In order to find out the correlations among the variables in the general model and set up a solid foundation for the later empirical tests, we have the following Pearson correlation analysis. Here is the table of results of Pearson correlation test for variables we use in this paper: all the tests are two-tailed. We use ${ }^{* * *}$ to indicate a level of significance at $1 \%,{ }^{* *}$ at $5 \%$ and ${ }^{*}$ at $10 \%$ (Table 12 ).

From the above table, we discover that MODY and IDXYRRET are closely, significantly and positively correlated, which is a very interesting phenomenon in Chinese capital market, named "Collective Action with Market Index". Liability-asset ratio and size of the enterprise are also significantly correlated with the performance of the enterprise. All independent variables and controlled variables are significantly correlated 
Table 10. Descriptive statistics when CTRLPCTSTATE $=1$.

\begin{tabular}{cccccc}
\hline Variable & Obs. & Mean & Std. Dev & Min & Max \\
\hline MODY & 704 & -0.3368 & 0.7604 & -2.3324 & 1.7938 \\
MODX & 704 & 0.0022 & 0.3589 & -2.2300 & 1.8300 \\
IDXYRRET & 704 & -0.1393 & 0.5422 & -0.6538 & 0.7980 \\
LEVRATIO & 704 & 0.4854 & 0.2125 & 0.0019 & 1.1480 \\
SIZE & 704 & 22.3762 & 1.2663 & 19.5269 & 25.4349 \\
INDUSTRY & 704 & 4.9788 & 3.3634 & 1.0000 & 17.0000 \\
\hline
\end{tabular}

Table 11. Descriptive statistics when CTRLPCTSTATE $=0$.

\begin{tabular}{cccccc}
\hline Variable & Obs. & Mean & Std. Dev. & Min & Max \\
\hline MODY & 705 & -0.1580 & 0.7043 & -2.2251 & 1.7565 \\
MODX & 705 & -0.0073 & 0.2924 & -2.0300 & 4.1500 \\
IDXYRRET & 705 & -0.0129 & 0.5080 & -0.6538 & 0.7980 \\
LEVRATIO & 705 & 0.5089 & 0.2181 & 0.0069 & 3.1462 \\
SIZE & 705 & 22.0387 & 1.2001 & 19.2886 & 25.4349 \\
INDUSTRY & 705 & 5.1347 & 3.6775 & 1.0000 & 17.0000 \\
\hline
\end{tabular}

Table 12. Pearson correlation test on the variables in the general model.

\begin{tabular}{ccccccc}
\hline Variables & MODY & MODX & IDXYRRET & LEVRATIO & SIZE & INDUSTRY \\
\hline MODY & 1 & & & & & \\
MODX & $0.0975^{* * *}$ & 1 & & & \\
IDXYRRET & $0.8038^{* * *}$ & $-0.0698^{* * *}$ & 1 & & & \\
LEVRATIO & $-0.0249^{*}$ & $-0.0309^{* *}$ & -0.0191 & 1 & 1 & \\
SIZE & $-0.032^{* *}$ & -0.0226 & $-0.035^{* * *}$ & $0.2926^{* * *}$ & 1 \\
INDUSTRY & 0.012 & 0.0184 & -0.0047 & -0.0023 & $0.0293^{* *}$ & 1 \\
\hline
\end{tabular}

with dependent variable, and all independent variables and controlled variables are not inter-correlated since the coefficients of correlation are below 0.6.

Here is the table of results of Pearson correlation test for variables author uses in this paper after grouping with the indicator DELSTATEPCT (Table 13 and Table 14).

From these two tables, we denote that MODY and IDXYRRET are still significantly correlated, while the correlation between MODY and other independent variables and controlled variables are not significant, which double-proves the previously-mentioned phenomenon called "Collective Action with Market Index". And still, all independent variables and controlled variables are not inter-correlated since the coefficients of correlation are below 0.6 .

Here is the table of results of Pearson Correlation Test for variables author uses in this paper after grouping with the indicator LGSTCHGIDX (Table 15 and Table 16). 
Table 13. Pearson correlation test when DELSTATEPCT $=1$.

\begin{tabular}{ccccccc}
\hline Variables & MODY & MODX & IDXYRRET & LEVRATIO & SIZE & INDUSTRY \\
\hline MODY & 1 & & & & \\
MODX & $0.2133^{* * *}$ & 1 & & & \\
IDXYRRET & $0.7986^{* * *}$ & 0.0005 & 1 & 1 & \\
LEVRATIO & 0.0450 & -0.0762 & 0.0528 & $0.3933^{* * *}$ & 1 & \\
SIZE & 0.0547 & -0.0286 & 0.0934 & 0.0340 & -0.0209 & 1 \\
INDUSTRY & 0.0344 & $0.1273^{* *}$ & 0.0084 & 0.094 \\
\hline
\end{tabular}

Table 14. Pearson correlation test when DELSTATEPCT $=0$.

\begin{tabular}{ccccccc}
\hline Variables & MODY & MODX & IDXYRRET & LEVRATIO & SIZE & INDUSTRY \\
\hline MODY & 1 & & & & & \\
MODX & 0.0358 & 1 & & & & \\
IDXYRRET & $0.8747^{* * *}$ & $-0.0946^{* * *}$ & 1 & & & \\
LEVRATIO & 0.0181 & $-0.0602^{* * *}$ & 0.0249 & 1 & 1 & \\
SIZE & -0.0399 & -0.0419 & 0.0376 & $0.3286^{* * *}$ & 1 \\
INDUSTRY & -0.0192 & 0.033 & -0.0164 & -0.0223 & 0.0188 & 1 \\
\hline
\end{tabular}

Table 15. Pearson correlation test when LGSTCHGIDX $=1$.

\begin{tabular}{ccccccc}
\hline Variables & MODY & MODX & IDXYRRET & LEVRATIO & SIZE & INDUSTRY \\
\hline MODY & 1 & & & & & \\
MODX & 0.0783 & 1 & & & & \\
IDXYRRET & $0.8267^{* * *}$ & $-0.2497^{*}$ & 1 & & & \\
LEVRATIO & -0.0083 & 0.0613 & -0.0023 & 1 & 1 & \\
SIZE & 0.0392 & $0.2311^{*}$ & -0.0238 & $0.5664^{* * *}$ & 1 \\
INDUSTRY & -0.0295 & 0.0764 & -0.0782 & -0.1725 & -0.0975 & 1 \\
\hline
\end{tabular}

Table 16. Pearson correlation test when LGSTCHGIDX $=0$.

\begin{tabular}{ccccccc}
\hline Variables & MODY & MODX & IDXYRRET & LEVRATIO & SIZE & INDUSTRY \\
\hline MODY & 1 & & & & & \\
MODX & 0.0063 & 1 & & & & \\
IDXYRRET & $0.8802^{* * *}$ & -0.0909 & 1 & & & \\
LEVRATIO & 0.0496 & -0.0607 & 0.0265 & 1 & 1 & \\
SIZE & 0.0262 & $-0.152^{* *}$ & $0.1106^{*}$ & $0.2737^{* * *}$ & 1 \\
INDUSTRY & -0.0106 & 0.0963 & 0.0253 & -0.0667 & 0.0665 & 1 \\
\hline
\end{tabular}


The result is quite similar with the table above, a very significant positive correlation between MODY and IDXYRRET. And liability-asset ratio is also significantly positively correlated with size of the company. And still, all independent variables and controlled variables are not inter-correlated since the coefficients of correlation are below 0.6.

Here is the table of results of Pearson correlation test for variables author uses in this paper after grouping with the indicator CTRLPCTSTATE (Table 17 and Table 18).

The result is quite similar with the table above; because of the limitation of length, no more tautology here. And still, all independent variables and controlled variables are not inter-correlated since the coefficients of correlation are below 0.6 .

All the above Pearson correlation analysis on the variables in the general model and grouping indicators build a solid base for the empirical tests in next section.

\section{Empirical Analysis}

In order to evaluate the statistical ties between state-owned capital and corporate earnings responses, we conduct an empirical test based on the general model described in Section 3. In this section, we also do a robust test to enhance the results in the empirical test.

\subsection{Empirical Test Results}

The table below is the results of empirical researches based on the general model or Equation (1), using the Ordinary-Least-Square method to analyze data that have been

Table 17. Pearson correlation test when CTRLPCTSTATE $=1$.

\begin{tabular}{ccccccc}
\hline Variables & MODY & MODX & IDXYRRET & LEVRATIO & SIZE & INDUSTRY \\
\hline MODY & 1 & & & & & \\
MODX & 0.0624 & 1 & & & & \\
IDXYRRET & $0.8575^{* * *}$ & $-0.1128^{* * *}$ & 1 & & & \\
LEVRATIO & -0.0523 & -0.0248 & 0.0032 & 1 & & \\
SIZE & 0.059 & -0.0115 & $-0.0568^{*}$ & $0.3235^{* * *}$ & 1 & \\
INDUSTRY & 0.046 & $0.0655^{*}$ & -0.0188 & $-0.1214^{* * *}$ & 0.0501 & 1 \\
\hline
\end{tabular}

Table 18. Pearson correlation test when CTRLPCTSTATE $=0$.

\begin{tabular}{ccccccc}
\hline Variables & MODY & MODX & IDXYRRET & LEVRATIO & SIZE & INDUSTRY \\
\hline MODY & 1 & & & & & \\
MODX & $0.1041^{* * *}$ & 1 & & & & \\
IDXYRRET & $0.843^{* * *}$ & -0.0332 & 1 & & & \\
LEVRATIO & $-0.0648^{*}$ & $0.0829^{* *}$ & $-0.0592^{*}$ & 1 & & \\
SIZE & $0.0643^{*}$ & -0.024 & -0.0451 & $0.2537^{* * *}$ & 1 & \\
INDUSTRY & -0.0481 & 0.0011 & 0.0106 & 0.0071 & $-0.0619^{*}$ & 1 \\
\hline
\end{tabular}


grouped by three indicators respectively. Similar as the specifications in Pearson correlation tests, all the significance level are two-tailed, and ${ }^{* * *}$ stands for the significant level at $1 \%,{ }^{* *}$ for $5 \%$ and ${ }^{*}$ for $10 \%$ (Table 19).

According to the definition of earnings respond coefficient (ERC), a higher ERC enjoys a higher earnings quality. The table above illustrates that companies favored by state-owned capital after the reform of non-tradable shares, either in the form of inflow and outflow of state-owned capital or gain and maintain control, have a significant higher ERC than those who are not. Especially those whose largest shareholder is converted from private to state-owned have a much higher ERC (0.6770) than those whose largest shareholder converts from state-owned to private $(0.2040)$. It could be clearly observed that change of the identity of the largest shareholder provokes the strongest reactions in the capital market, and control of state-owned capital is viewed as a favor.

The second strongest reaction for the behavior of state-owned capital is the change of holding ratio of state-owned shares. Considering the gradual process of significant alteration of equities under the supervision and regulation from CSRC and other administrative, change of holding ratio of state-owned shares is not as obvious as the change of identity of the largest shareholder, because of the inherent large portion owned by state. Thus, the market does not react as strongly as the previous occasion.

However, the difference between companies of which holding ratio of state-owned shares is above the median (0.3410) and those below the median (0.3322) is not very obvious, but very significant. This result is the same with some previous studies [3]-[7]. Thus, the entire three hypothesis proposed at the beginning of this paper are verified.

Another fact we notice is the coefficient of IDXYRRET, which is not only positive but also very significant. Actually, the coefficient of IDXYRRET is rather stable comparing to ERC, which ranges from 0.2040 to 0.6770 . This, once again, convinces the phenomenon we mention before, "Collective Action with Market Index".

Two of the controlled variables, LEVRATIO and INDUSTRY, are not significant in most models, which, however, is contrary to some previous studies [8]-[14]. However, as controlled variables, LEVRATIO and INDUSTRY are indispensable in this model.

Table 19. General model results: State-owned capital and earnings quality.

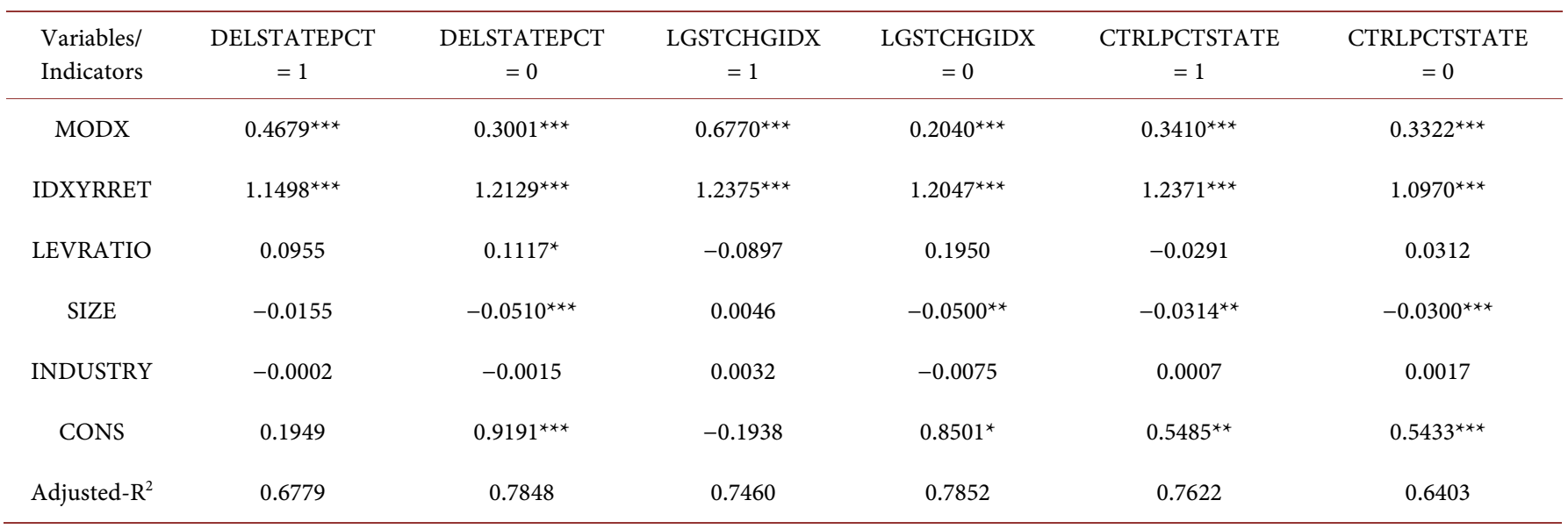


In conclusion, companies with state-owned capital in their equity structure tend to have a higher earnings quality compared to those without state-owned capital.

\subsection{Robustness Verification}

To strengthen the stability of our conclusion, a robust test is helpful. In order for a robust test, we revise the general model in the empirical test by altering the independent variable MODX to MODX1, which is another measurement of change of EPS, with standardization of it by dividing last year's closing price.

$$
\begin{aligned}
\text { MODY } & =\alpha 1+\alpha 2 * \text { MODX } 1+\alpha 3 * \text { SIZE }+\alpha 4 * \text { LEVRATIO } \\
& +\alpha 5 * \text { IDXYRRET }+\alpha 6 * \text { INDUSTRY }
\end{aligned}
$$

The table below shows the results of robust tests based on the general model, using the Ordinary-Least-Square method to analyze data that have been grouped by three indicators respectively (Table 20).

As we can observe from the table above, results of robustness test are in accordance with empirical researches we conduct before, i.e. companies favored by state-owned capital enjoys a higher earnings quality than those not. Although results of absolute number of the ERC coefficient are different from the previous empirical results and the intensity of market reaction of first two indicators is different from the previous results, the fundamental conclusion we draw is still the same. What's more, the phenomenon of "Collective action with the market index" is still very significant and stable.

\section{Conclusions and Discussions}

Evidence from empirical researches supports the opinion that state-owned capital does enhance the earnings quality in Chinese capital market in post reform of non-tradable shares era, which also verifies the entire three hypotheses provided at the very beginning of this paper. Among all the three situations where state-owned capital influences the equity structure of a listed company, change of the identity of the largest shareholder and change of the holding ratio of state-owned shares provoke stronger market reaction. These results, however, are contradicted with many previous studies done

\begin{tabular}{|c|c|c|c|c|c|c|}
\hline $\begin{array}{l}\text { Variables } \\
\text { Indicators }\end{array}$ & $\begin{array}{c}\text { DELSTATEPCT } \\
=1\end{array}$ & $\begin{array}{c}\text { DELSTATEPCT } \\
=0\end{array}$ & $\begin{array}{c}\text { LGSTCHGIDX } \\
=1\end{array}$ & $\begin{array}{c}\text { LGSTCHGIDX } \\
=0\end{array}$ & $\begin{array}{c}\text { CTRLPCTSTATE } \\
=1\end{array}$ & $\begin{array}{c}\text { CTRLPCTSTATE } \\
=0\end{array}$ \\
\hline MODX1 & $4.2202^{\star * *}$ & $1.6729^{* * *}$ & $3.4197^{\star}$ & $1.3635^{\star}$ & $0.3410^{* * *}$ & $0.3322^{* * *}$ \\
\hline IDXYRRET & $1.1476^{* * *}$ & $1.2103^{\star * *}$ & $1.1972^{\star * *}$ & $1.2031^{\star * *}$ & $1.2371^{\star * *}$ & $1.0974^{* * *}$ \\
\hline LEVRATIO & 0.1196 & $0.1388^{\star *}$ & -0.1509 & 0.1989 & -0.0291 & 0.0312 \\
\hline INDUSTRY & 0.0029 & -0.0017 & 0.0024 & -0.0059 & 0.0007 & 0.0017 \\
\hline CONS & 0.2808 & $0.9784^{\star * *}$ & -0.9153 & $1.0040^{* *}$ & $0.5485^{\star *}$ & $0.5433^{* * *}$ \\
\hline ADJUSTED-R^2 & 0.6636 & 0.7757 & 0.6833 & 0.7622 & 0.7622 & 0.6403 \\
\hline
\end{tabular}

Table 20. Robustness test results. 
before the completion of reform of non-tradable shares in 2007, such as [8]-[12], etc. while some later studies, such as [3]-[7], draw to the same conclusion with ours.

Another phenomenon we notice is the "Collective action with market index", which is not only very significant but also very stable. This, in fact, is identical with expectations and common sense in Chinese capital market. All of the listed companies, whether state-owned or private-owned, are deeply influenced by the macro scope of the whole market.

We suppose that following reasons might differentiate results of this paper from previous studies holding the contrary opinion.

First, the background of this empirical research is after the completion of reform of non-tradable shares in most companies, which means the liquidity of the whole market increases greatly, from a market where almost sixty percent of total shares cannot be traded to a so-called "Entire circulation" circumstance theoretically. This will inevitably lead to great changes in corporations' equity structure and corporate governance. Therefore, the conclusion before might not apply to a relatively new situation;

Next, with the loosening up of restrictions, state-owned capital would function in a more market-oriented way. Even though administrative intervenes are still noticeable, capital still remains its origin of pursing profit, whose form is inflow to high-quality enterprises in expectation of a higher return in capital market, in a gradually liberalized market. Thus, companies favored by state-owned capital might be of high quality to some degree;

Third, even though there are many criticisms about the backwards management and inefficiency of state-owned enterprises, it is undeniable that state-owned enterprises do have some natural advantages under the current Chinese characteristic market economy system, especially in monopolized industries. This idea, however, is similar to the view proposed in [15], saying that state-owned enterprises have a better earnings quality in industries which are not very competitive.

Finally, just as previously-mentioned at the beginning of paper, heavy control of stateowned capital can eliminate resistance of implementing policies, which can enhance efficiency; even from empirical evidence the enhancement is not obvious but significant.

Based on the results of empirical researches, we think that there is one suggestion for the investors: Please keep an open eye to any significant alteration in corporate equity structure, especially the holding ratio changes of state-owned shares, because any significant change of the equity structure of a listed company may lead to great differences to corporate governance and earnings quality, and the behavior of state-owned capital should be focused, particularly nowadays after the completion of reform of non-tradable shares. An inflow of huge amount of state-owned capital may not be considered as a welcomed event in Western capital market, but in China, it might be an indicator of good news of earnings quality and even explicit favor given by the government.

\section{Acknowledgements}

We thank the editors for their supports and the referees for their comments. 


\section{References}

[1] Chen, X.R. and Xu, X.D. (2001) Equity Structure, Company Performance and Protection of Investor's Interests. Economic Research Journal, 11, 3-11.

[2] Shen, H.H., Huang, Z.K. and Wu, L.S. (2009) The Earnings Quality Effect of Reform of Non-Tradable Shares. Accounting Research, 8, 40-48.

[3] Sun, L. and Liu, C. (2008) What Makes the Differences of Earnings Management: Corporate Governance or Business Performance?-Evidence from China Stock Markets. China Accounting Review, 1, 79-92.

[4] Yu, N.T., Shen, Z.H. and Liu, M.H. (2008) Ownership Structure and Earnings QualityData from Shanghai and Shenzhen Stock Market. Journal of Shanxi Financial and Economic University, No. 8, 107-114.

[5] Wang, K.M., Lian, P. and Xiang, Y. (2009) The Origin of Listed Companies and Earnings Quality. China Accounting Review, 1, 3-28.

[6] Wang, B. (2008) Large Shareholder Control, Property Arrangement and Corporate Earnings Quality-Data from Chinese Listed Companies. Journal of Shanxi Financial and Economic University, 1, 67-72.

[7] Gu, M.R., Yang, J.W. and Yu, N.T. (2012) Ownership Attributes, Corporate Governance and Real Earnings Management. China Accounting Review, 3, 255-274.

[8] Sun, Y.X. (2001) Ownership, Equity Structure and Corporate Governance Mechanism. Economic Research Journal, 1, 45-53.

[9] Sun, Q. and Tong, W.H.S. (2003) China Share Issue Privatization: The Extent of Its Success. Journal of Financial Economics, 70, 183-222. http://dx.doi.org/10.1016/S0304-405X(03)00145-4

[10] Xu, X.D. and Chen, X.R. (2003) First Major Shareholder's Influences on Corporate Governance and Company Performance. Economic Research Journal, 2, 64-74.

[11] Liu, L.G. and Du, Y. (2003) An Empirical Research on the Relationship of Corporate Governance and the Quality of Accounting Information. Accounting Research, 2, 28-36.

[12] Wang, H.C. and Tong, Y. (2006) Controlling Shareholder and Earnings Quality-An Empirical Study Based on Earnings Response Coefficients. Accounting Research, 2, 66-74.

[13] Zhu, C.F. and Li, Z.W. (2008) State Ownership and Accounting Conservatism. Accounting Research, 5, 38-45.

[14] Yu, P. (2007) Equity Structure and Financial Report Restatement-Evidence from Listed Companies. Economic Research Journal, 9, 134-144.

[15] Chen, X. and Jiang, D. (2000) Equity Diversification, Company Performance and Industrial Competition. Economic Research Journal, 8, 28-35. 
Submit or recommend next manuscript to SCIRP and we will provide best service for you:

Accepting pre-submission inquiries through Email, Facebook, LinkedIn, Twitter, etc. A wide selection of journals (inclusive of 9 subjects, more than 200 journals)

Providing 24-hour high-quality service

User-friendly online submission system

Fair and swift peer-review system

Efficient typesetting and proofreading procedure

Display of the result of downloads and visits, as well as the number of cited articles

Maximum dissemination of your research work

Submit your manuscript at: http://papersubmission.scirp.org/

Or contact jmf@scirp.org 